\title{
Erişkin başlangıçıı kalıtsal metabolik hastalıklar: tek merkez deneyimi
}

\author{
Adult onset inherited metabolic diseases: a single center experience
}

\author{
Burcu Öztürk Hişmi
}

Öz

Amaç: Kalıtsal metabolik hastalıklar $(\mathrm{KMH})$, insan biyokimyasal yolaklarında görev alan tüm moleküllerin kalıtsal bozukluklarını kapsayan oldukça geniş bir hastalık grubudur. Tedavi edilme potansiyelleri ile öne çıkan KMH'lar, ilk bulgularını erişkin yaşta da verebilirler. Bu çalışma ile kliniğimizde erişkin yaşta kalıtsal metabolik hastalık tanısı alan olguların klinik fenotipleri ve tanısal özellikleri derlenerek, bu konuda farkındalık yaratılması amaçlanmıştır.

Gereç ve yöntem: Erişkin yaşta KMH tanısı almış olguların dosyaları geriye dönük olarak incelenmiştir.

Bulgular: Yaşları 19-88 yıl arasında değişen, 14 aileden 39 erişkin olguya 9 özgül KMH tanısı konulmuştur; Fabry Hastalığı (\%59), Sitrin eksikliği (\%10), Multipl açil-KoA dehidrogenaz eksikliği (\%8), Alkaptonüri (\%8), Adrenolökodistrofi (\%5), ve birer olgu ile Akut intermitan porfiri, Serebral kreatin transport bozukluğu, Mitokondriyal nörogastrointestinal ensefalomiyelopati, Ornitin transkarbamilaz eksikliği. Olguların \%80'i aile taramasında, \%18'i klinik bulgularla, \%2'si selektif tarama ile tanı almıştır. Tanı esnasında olguların \%77'si semptomatik, \%23'ü asemptomatiktir. Semptomatik olguların hastanede ilk başvurdukları klinikler nöroloji (\%30), nefroloji (\%14), göğüs hastalıkları (\%14), ortopedi (\%10), dahiliye (\%7) ve kardiyolojidir (\%7). Semptomatik olguların \%60'ına KMH tanısı biyokimyasal testler ile konulmuştur. Olgularımızın \%93'ü için hastalığa spesifik tedavi mevcut olup, ancak takipsizlik ya da tedavi reddi nedeniyle sadece \%67'sine tedavi uygulanabilmiştir.

Sonuç: Erişkin başlangıçlı kalıtsal metabolik hastalıklar konusunda farkındalığın artması hastaların erken tedavi olmalarını sağlayarak morbidite ve mortaliteyi azaltacaktır. Kalıtsal metabolizma hastalıkları alanında özelleşmiş erişkin branş hekimlerinin yetişmesine ihtiyaç vardır.

Anahtar kelimeler: Kalıtsal metabolik hastalık, erişkin, fabry, sitrin eksikliği, porfiri.

Öztürk Hişmi B. Erişkin başlangıçlı kalıtsal metabolik hastalıklar: tek merkez deneyimi. Pam Tıp Derg 2021;14:692-705.

\begin{abstract}
Purpose: Inherited metabolic diseases (IMDs), are genetic diseases of human biochemical pathways and can present at adulthood. IMDs, which stand out for their potential to be treated, can also make their first findings in adulthood. In this study, we aimed to document clinical and diagnostic features of the patients with adult onset IMDs in our clinic and to raise awareness on this subject.

Materials and methods: Medical files of patients diagnosed with IMD at adulthood were retrospectively analyzed.

Results: 39 adult cases from 14 families, aged between 19-88 years, were diagnosed with 9 specific IMDs; Fabry disease (59\%), Citrin deficiency (10\%), Multiple acyl-CoA dehydrogenase deficiency (8\%), Alkaptonuria $(8 \%)$, Adrenoleukodystrophy $(5 \%)$, and Acute hepatic porphyria, Cerebral creatine transport defect, Mitochondrial neurogastrointestinal encephalomylopathy, Ornithine transcarbamylase deficiency. The cases were diagnosed with family screening in $80 \%$, clinical findings in $18 \%$, and selective screening in $2 \% .77 \%$ of the cases were symptomatic and $23 \%$ were asymptomatic at the time of diagnosis. The outpatient clinics where the symptomatic patients had first admitted were neurology (30\%), nephrology (14\%), chest diseases (14\%), orthopedics $(10 \%)$, internal medicine $(7 \%)$ and cardiology $(7 \%)$. In symptomatic cases, the diagnosis of IMD was made by biochemical tests in $60 \%$. Disease-specific treatments were available for $93 \%$, but $67 \%$ were treated due to patient refusal of treatment or lost to follow-up.

Conclusion: Morbidity and mortality related to adult-onset inherited metabolic diseases can be reduced, by increasing awareness and timely management. There is a need for dedicated physicians, trained to diagnose and manage adult patients with IMDs.
\end{abstract}

Key words: Inherited metabolic disease, adult, fabry, citrin deficiency, porphyria.

Ozturk Hismi B. Adult onset inherited metabolic diseases: a single center experience. Pam Med J 2021;14:692705.

Burcu Öztürk Hişmi, Dr. Öğr. Üye. Marmara Üniversitesi Tıp Fakültesi, Çocuk Sağlığı ve Hastalıkları Anabilim Dalı, Çocuk Metabolizma Hastalıkları Bilim Dalı, İstanbul, Türkiye, e-posta: bhismi@gmail.com (https://orcid.org/0000-0001-7146-0248) (Sorumlu Yazar) 


\section{Giriş}

Kalıtsal metabolik hastalıklar (KMH), biyokimyasal yolaklarda enzim, kofaktör, taşıyıcı protein vb. görev alan tüm moleküllerin kalıtsal bozukluklarını kapsayan oldukça geniş bir hastalık grubudur [1]. Yirminci yüzyıl başlarında Dr. Archibald Garrod öncülügünde bir grup klinisyen, hastaların vücut sıvıları ile yaptıkları araştırmalarda anormal metabolitler saptamışlar ve insanın doğası (nature) ile besini (nurture) arasındaki birtakım uyumsuzluklar sonucu oluştuklarını düşündükleri bu hastalıklar için ilk kez "metabolizmanın doğumsal hataları" (inborn errors of metabolism) ifadesini kullanmışlardır [2]. İnsan doğasının genetik temelinin anlaşıması ile "kalıtsal metabolik hastalıklar" (inherited metabolic diseases) ifadesi daha sık kullanılmaya başlanmıştır. Diyet tedavisi, Fenilketonüri başta olmak üzere bazı KMH'ların doğal seyrini değiştirerek modern tıp için çığır açıCı olmuştur. Bu hastalıkların kalıcı hasar oluşmadan erken saptanabilmesi için yenidoğan tarama programları geliştirilmiştir. Günümüzde yaklaşık 1200 tanımlanmış KMH mevcut olup, genetik tanı yöntemlerinin geliştirilmesi ve gen fonksiyonlarının anlaşılması ile bu sayı her geçen gün artmaktadır [3].

Ülkemizde $\mathrm{KMH}$ alanındaki tek formal eğitim, çocuk sağlığı ve hastalıkları uzmanlarına yönelik "çocuk metabolizma hastalıkları" yan dal uzmanlık eğitimidir. İyileşen tanı ve tedavi imkanları ile artan sayıda KMH'ı çocuk erişkin yaşa ulaşmakta, çocukken semptomatik olmasına rağmen tanı alamayan ya da erişkin yaşta ilk kez yakınmaları başlayan bireyler de erişkin branş hekimlerine başvurmaktadırlar [4]. Nörolojik (inme, koma, miyopati, miyelopati, periferik nöropati, vb), psikiyatrik (psikoz, deliryum, kişilik bozukluğu), ortopedik (osteoartrit, dejeneratif artrit), göz (katarakt, koryoretinit), vb. özgül sistem etkilenmesi olan erişkin $\mathrm{KMH}$ olguları hekimlerin üstün çabaları ile tanı alabilmektedirler [5].

Fakülte ve uzmanlık eğitimleri sırasında ayırıcı tanılar arasında sıklıkla KMH'lar ile karşılaşan, ancak kimde, ne zaman, hangi özgül kalıtsal metabolik hastalığı düşünmesi gerektiğini, tanı ve tedavi sürecini gerçek yaşamda tecrübe edemeyen çoğu hekim için, bu hastalıklar "görünmez" hale gelmektedir. Örneğin, ani bilinç değişikliği ile acil servise getirilen, öncesinde tamamen sağılılı bir genç erişkin olguda zehirlenme öngörülerek kanda alkol, uyuşturucu madde, vb. toksik maddeler araştırıırken, bilinen en toksik maddelerden biri olan "amonyak" sıklıkla akla gelmemektedir. Plazma amonyak düzeyine bakılmayan her akut nörolojik veya psikiyatrik tabloda hekim, bir üre döngüsü bozukluğu olgusunu yakalama ve minimum sekel ile iyileştirebilme olasılığından uzaklaşmaktadır [6]. Bu çalışma ile çocuk metabolizma hastalıkları pratiğinde, tanı ve tedavi sürecine dahil olunan erişkin $\mathrm{KMH}$ olgularının klinik bilgilerinin sunulması ve bu konuda farkındalık yaratı Iması amaçlanmıştır.

\section{Gereç ve yöntem}

Bu kesitsel, tanımlayıcı araştırmaya, Sağlık Bilimleri Üniversitesi İzmir Tepecik Eğitim ve Araştırma Hastanesi Çocuk Metabolizma Hastalıkları Kliniği'nde 3 yıl süresince Eylül 2015- Haziran 2018 ve Temmuz- Eylül 2019 arası) ayaktan ya da yatarken değerlendirilmiş ve özgül bir KMH tanısı almış, tanıda 18 yaş ve üzerinde olan bireyler dahil edilmiştir. Çocukluk çağında tanı alıp erişkin yaşa ulaşan bireyler çalışma dışı bırakılmıştır. Olguların dosyaları geriye dönük olarak incelenerek tanı yaşı, cinsiyet, özgül KMH tanısı, tanı şekli (klinik tanı, selektif tarama, aile taraması), tanı anındaki semptomlar, başvuru yakınması, tanısal önem taşıyan öykü, fizik muayene, temel laboratuvar, görüntüleme bulguları, tanısal test (biyokimyasal, genetik, vb.), uygulanan tedaviler (hastalığa özgü, semptomatik) kaydedilmiştir. Özgül KMH tanıları, Saudubray ve ark. [7] tarafından önerilen "basitleştirilmiş KMH sınıflamasına göre küçük molekül hastalıkları (zehirlenme tipi), kompleks molekül hastalıkları (organel bozuklukları) ya da enerji eksikliği hastalıkları şeklinde üç ana grupta toplanarak sunulmuştur. Çalışma, Sağlık Bilimleri Üniversitesi İzmir Tepecik Eğitim ve Araştırma Hastanesi Girişimsel Olmayan Araştırmalar Etik Kurulu tarafından onaylanmış ve Helsinki Bildirgesi doğrultusunda yapılmıştır. Tanımlayıcı istatistikler için IBM SPSS 23 programı kullanılmıştır.

\section{Bulgular}

Çalışmaya, yaşları 19 ile 88 arasında değişen (ortanca 36 yıl), 14 aileden 39 olgu dahil edilmiştir. (Tablo 1). Yirmi dört kadın (\%62) ve 15 erkek (\%38) olgunun yaş ortancaları sırası ile 31 (21-88 arası) ve 56 (19-71 arası) yıldır. 
Erişkin başlangıçlı kalıtsal metabolik hastalıklar: Çalışma grubunda en sık tanı konulan hastalık \%59 (n=23) ile Fabry Hastalığı olup, diğer hastalıkların dağılımı şu şekildedir; \%10 Sitrülinemi tip-2 (CTLN2; n=4), \%8 Multipl açil-KoA dehidrogenaz eksikliği (MADE; n=3), \%8 Alkaptonüri (AKU; n=3), \%5 Adrenolökodistrofi (ALD; $n=2$ ) ve birer olgu ile akut hepatik porfiri (Porfiri), serebral kreatin transport bozukluğu (SKTB), Mitokondriyel nörogastrointestinal ensefalomiyelopati (MNGIE), Ornitin transkarbamilaz eksikliği (OTCE). Basitleştirilmiş KMH sınıflandırmasına göre, olguların \%64'ü kompleks molekül hastalığı ( $n=25 ;$ Fabry, ALD), \%23'ü küçük molekül hastalığı ( $n=9$; CTLN2, AKU, OTCE, Porfiri), \%13'ü ise enerji eksikliği hastalığı $(n=5$; MADE, MNGIE, SKTD) tanısı almıştır (Tablo 1).

Kalıtsal metabolik hastalıkların tanı süreci ve klinik fenotipler: Erişkin $\mathrm{KMH}$ olgularının \%80'i $(n=31)$ aile taramasında, \%18'i $(n=7)$ klinik bulgularla, \%2'si $(n=1)$ ise selektif tarama (böbrek nakil ünitesinde Fabry taraması) ile tanı almışlardır. Aile taraması ile 5 erişkin indeks olgu üzerinden 23 olgu, 6 çocuk indeks olgu üzerinden ise 8 olgu tanı almıştır. Tanı anında 30 olgu (\%77) semptomatik iken, 9 olgu (\%23) asemptomatiktir. Semptomatik olguların klinik fenotipleri, ilk başvurdukları bölümler ve tanıları Tablo 2'de özetlenmiştir.

Semptomatik bireylerin en sık nöroloji (\%30), nefroloji $(\% 13,5)$, göğüs hastalıkları $(\% 13,5)$ ve romatoloji $(\% 10)$ olmak üzere toplam 10 farklı branşta uzman hekime başvurdukları görülmüştür. Periferik nöropati, nonkonvulsif status epileptikus, böbrek yetmezliği, proteinüri, kronik obstrüktif akciğer hastalığı, astım, disritmi, osteoartrit olgulardaki başlıca klinik fenotipler olup, klinik bulgular ile sadece 7 olgu (\%23) $\mathrm{KMH}$ tanısı alabilmiş, diğer 23 olgu (\%77) tarama çalışmaları ile saptanmıştır. Klinik tanı alan 7 olgudan 3 tanesinin (2 CTLN2, MNGIE) tanısı çocuk metabolizma bölümü tarafından kesinleştirilmiştir. Semptomatik olguların yarısını oluşturan Fabry hastalarının $(n=16)$, 10 farklı klinik tabloda 7 farklı branş hekimine başvurdukları ve ancak ikisinin (\%12) klinik tanı alabildiği dikkat çekmiştir (Resim 1-J, K).

Tanıda henüz asemptomatik olan 9 (\%23) olgunun hepsi kadın olup, yaş ortancaları 30 yıldır. X'e bağlı kalıtılan hastalıklar için heterozigot olan 21 kadın bireyden 12'si (\%57;
10 Fabry, 1 ALD, 1 SKTD) tanıda semptomatik olup, henüz asemptomatik olan 9 kadın bireye ise (7 Fabry, 1 OTCE, 1 ALD) hastalanma riskleri nedeniyle yıllık izlem önerilmiştir.

Kalıtsal metabolik hastalıklarda tanı yöntemleri: Klinik şüphe ya da aile taraması ile tanı konulan olguların \%49'unda ( $n=19)$ özgül $\mathrm{KMH}$ tanısı biyokimyasal test ile, \%51'inde $(n=20)$ ise genetik test ile kesinleştirilmiştir. Semptomatik olgularda biyokimyasal test ile tanı oranı \%60'tır. Biyokimyasal testlerden sıklık sırası ile; plazmada enzim ve biyobelirteç (lysoGb3) ölçümü ile Fabry $(n=10)$, idrar organik asitlerinde homogentisik asit saptanması ile $\operatorname{AKU}(n=3)$, plazma çok uzun zincirli yağ asitleri (ÇUZYA) ile ALD ( $n=2)$, plazma amino asitleri ile CTLN2 $(n=2)$, karnitin-açilkarnitin profili ile (Tandem MS) MADE $(n=1)$, idrar porfobilinojen ve porfirin analizi ile akut porfiri $(n=1)$ tanıları konulmuştur. Biyokimyasal yöntemlerin tanıda yeterli olmadığı 12 semptomatik (6 kadın Fabry, 2 CTLN2, 2 MADE, MNGIE, SKTD) ve 8 asemptomatik olguda (7 Fabry, 1 OTCE) genetik test ile tanı kesinleştirilmiştir. Genetik tanı yöntemi olarak, semptomatik indeks olgularda tek gen sekansı ya da genetik paneller, diğer bireylerde ise aile içi bilinen mutasyon taraması kullanılmıştır. Biyokimyasal yöntemlerle tanı alan olgularda tanı genetik çalışma ile de doğrulanmıştır, sadece akut porfiri olgusunun araştırması devam etmektedir. Hastalıkların kalıtım şekline göre olguların dağııımı ise \%69 X'e bağlı resesif (Fabry, ALD, OTCE, SKTD), \%28 otozomal resesif (CTLN2, MADE, AKU, MNGIE) ve \%3 otozomal dominant (Porfiri) kalıtım şeklindeydi.

Kalıtsal metabolik hastalıklarda uygulanan tedaviler ve izlem: Semptomatik 30 olgunun 28 (\%93)'i için hastalığa özgü tedavi mevcut olup, 20 olguya (\%67) tedavi verilmiştir. Yedi olgu tedavi almak istememiş (6 Fabry, 1 SKTD), ileri yaştaki bir Fabry olgusuna ise tedavi önerilmemiştir. Dokuz Fabry olgusunda enzim replasman tedavisi, 3 MADE olgusunda Riboflavin ve $3 \mathrm{AKU}$ olgusunda Nitisinon (NTBC), 1 CTLN2 olgusuna sodyum piruvat olmak üzere 16 olguya (\%53) tedavi başlanmıştır. Riboflavine yanıtsız 2 MADE olgusu ile enzim tedavisinden klinik fayda görmediğini düşünen 1 kadın Fabry olgusu kendi istekleri ile tedaviye devam etmek istememiştir. Üç AKU ve 4 CTLN2 olmak üzere 7 olguya hastalığa özel 


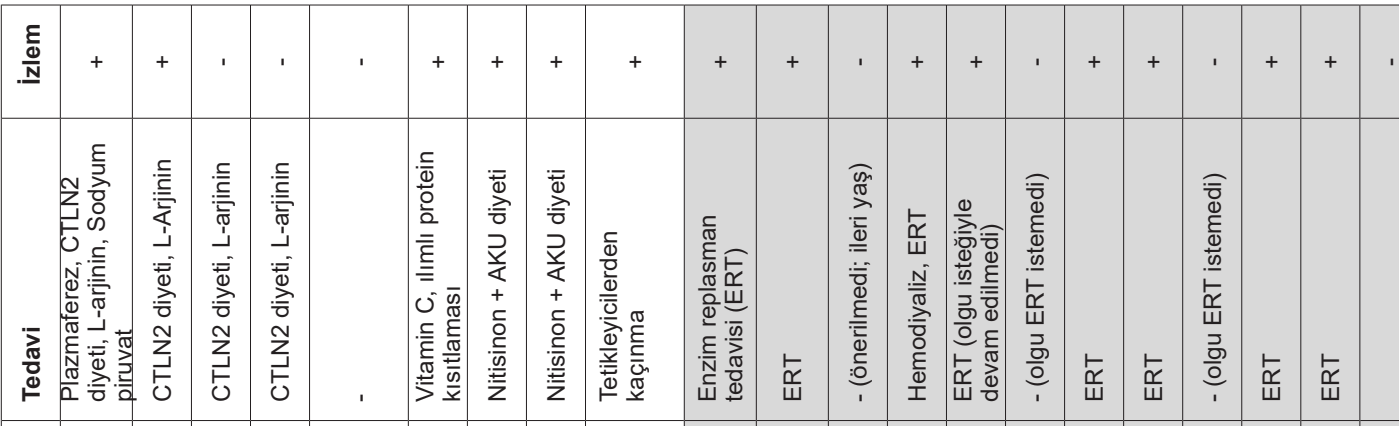

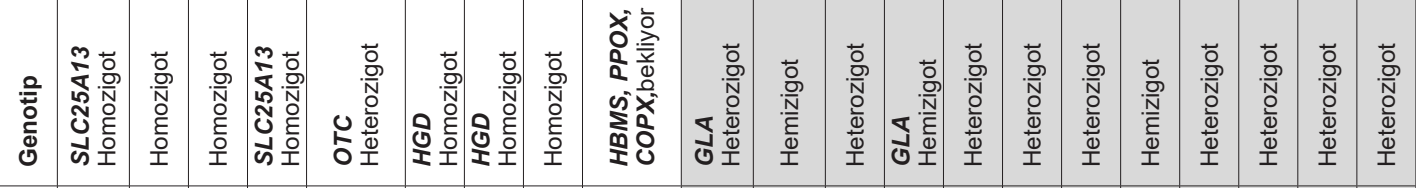

\begin{tabular}{|c|c|c|c|c|c|c|c|c|c|c|c|c|c|c|c|c|c|c|c|}
\hline 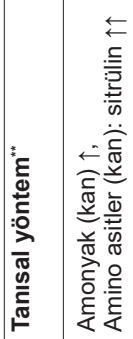 & 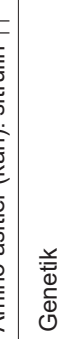 & 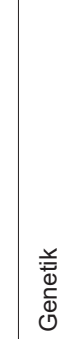 & 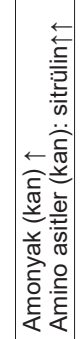 & 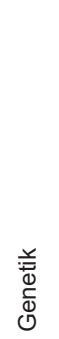 & 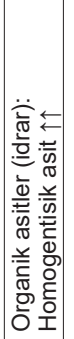 & & 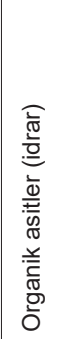 & 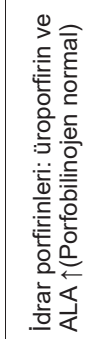 & 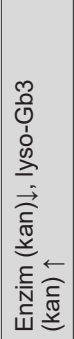 & 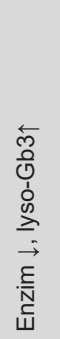 & 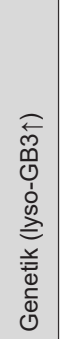 & 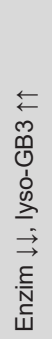 & 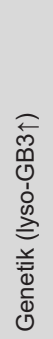 & 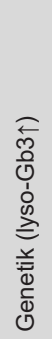 & 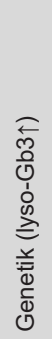 & 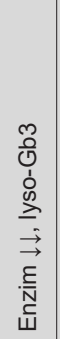 & 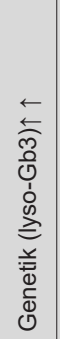 & 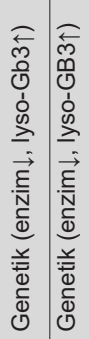 & 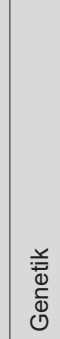 \\
\hline
\end{tabular}

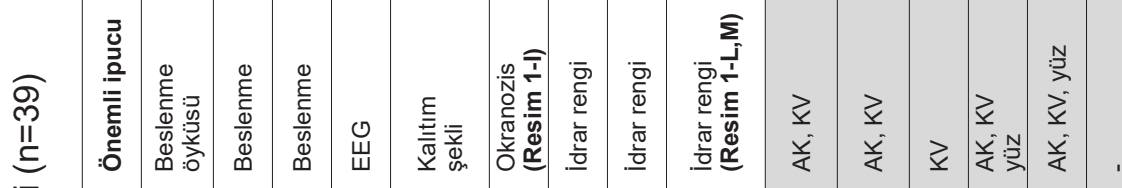

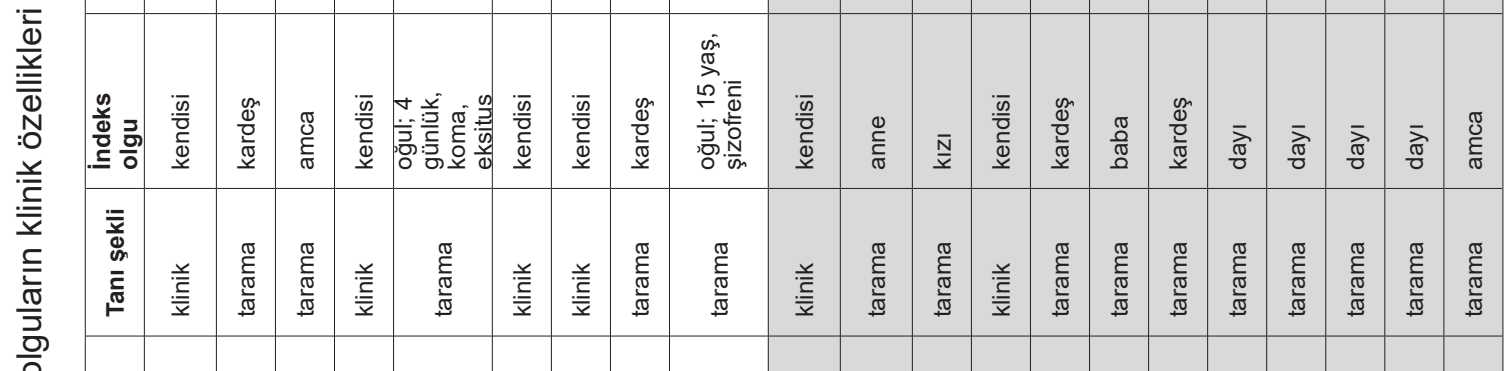

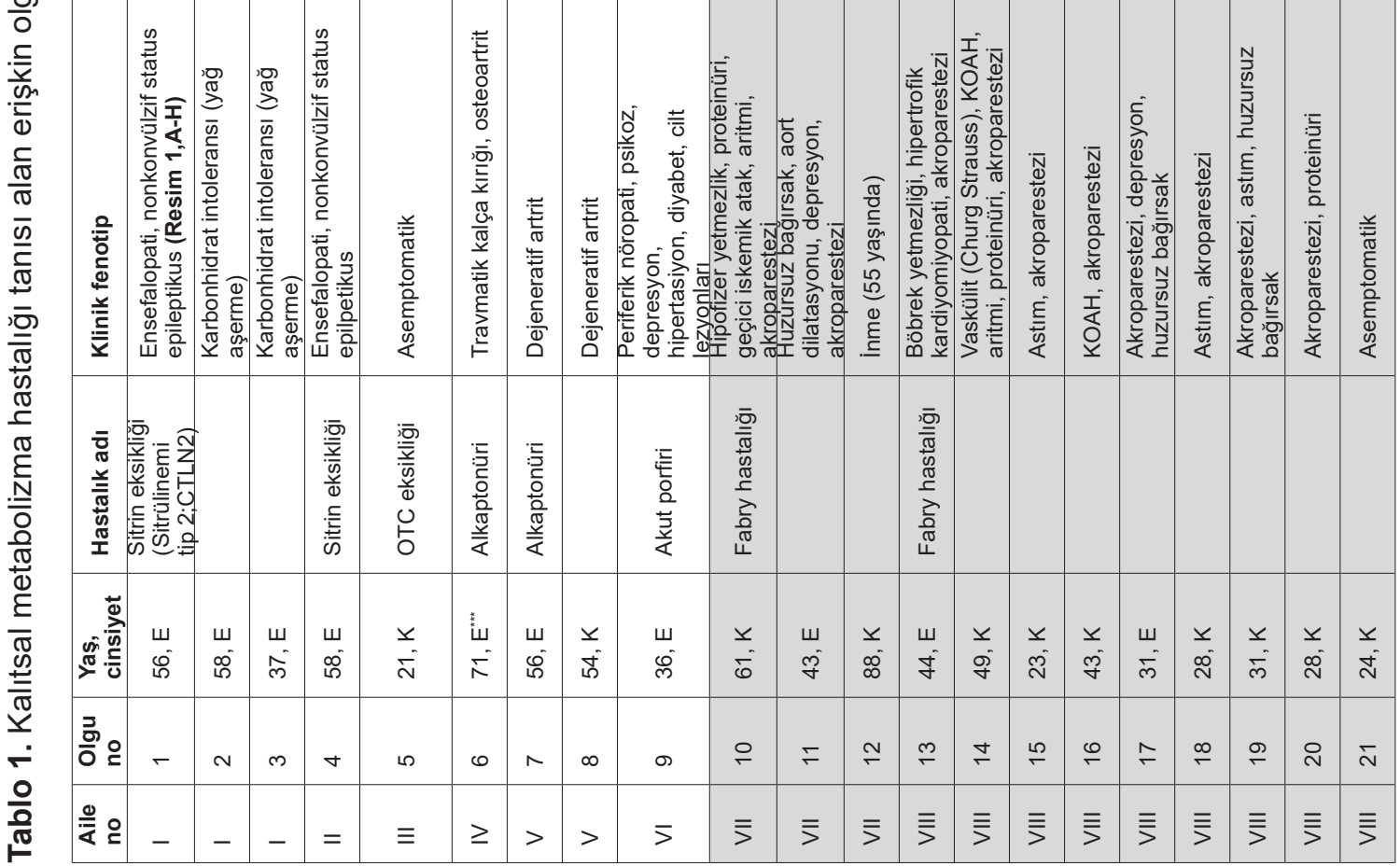




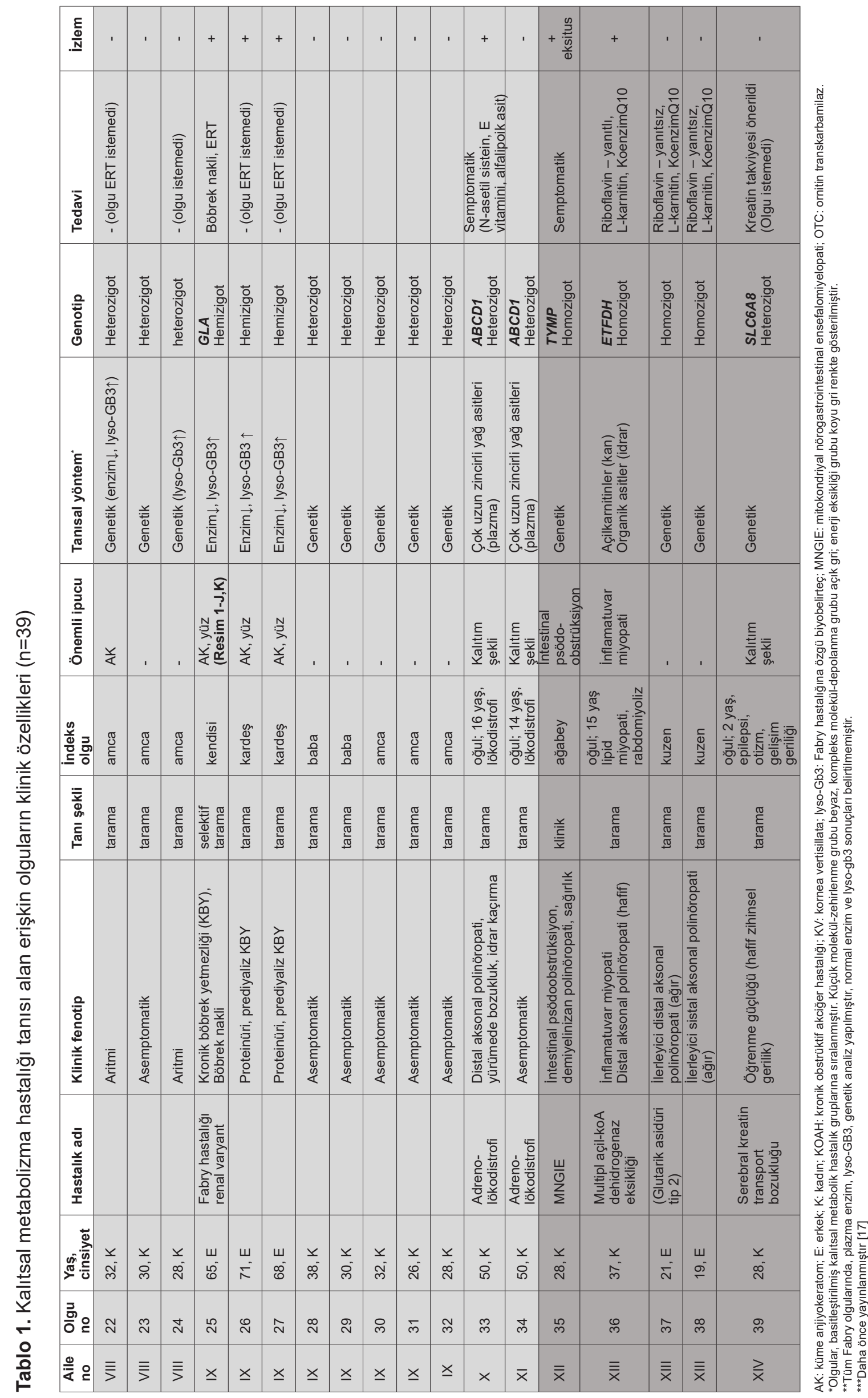




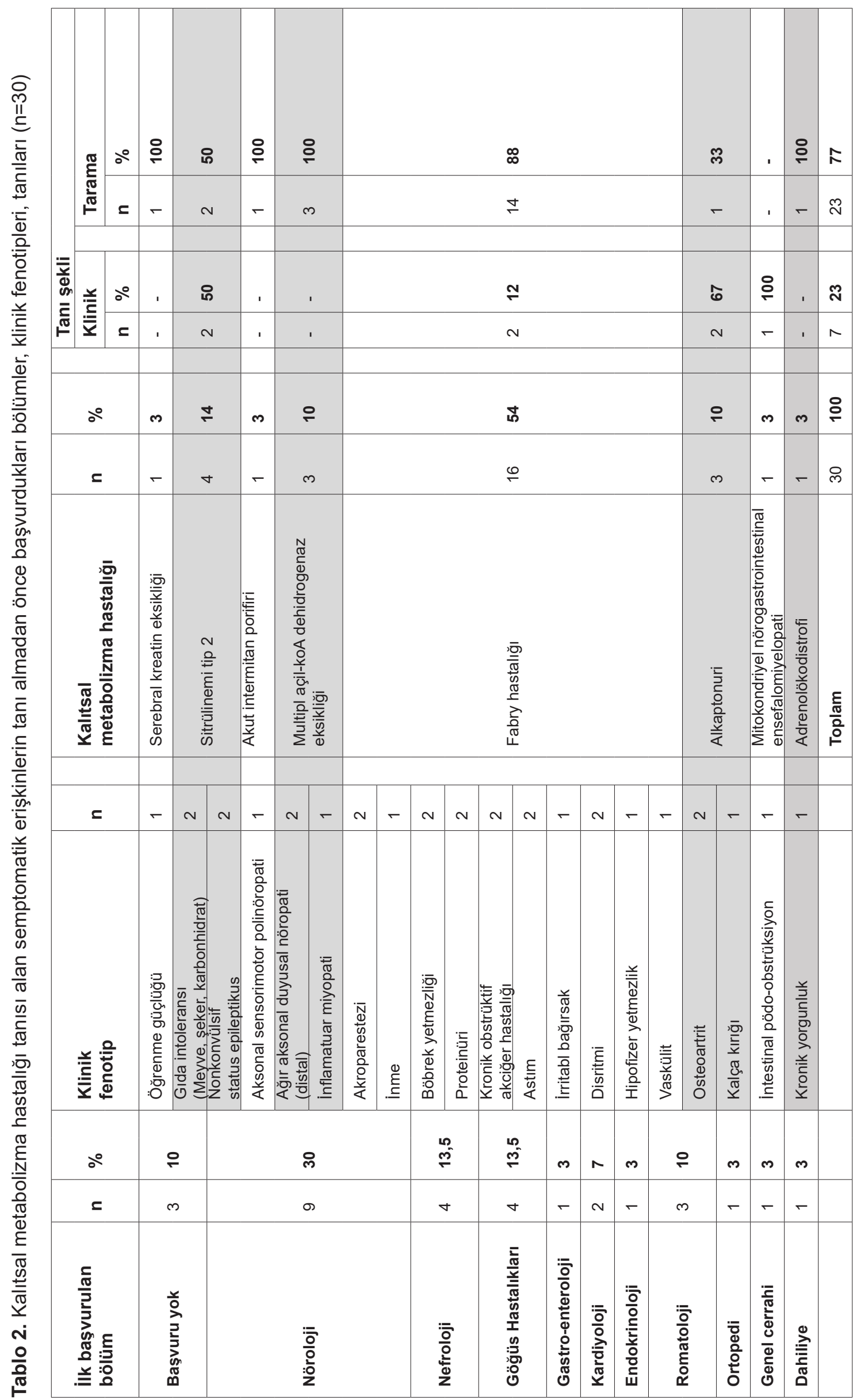




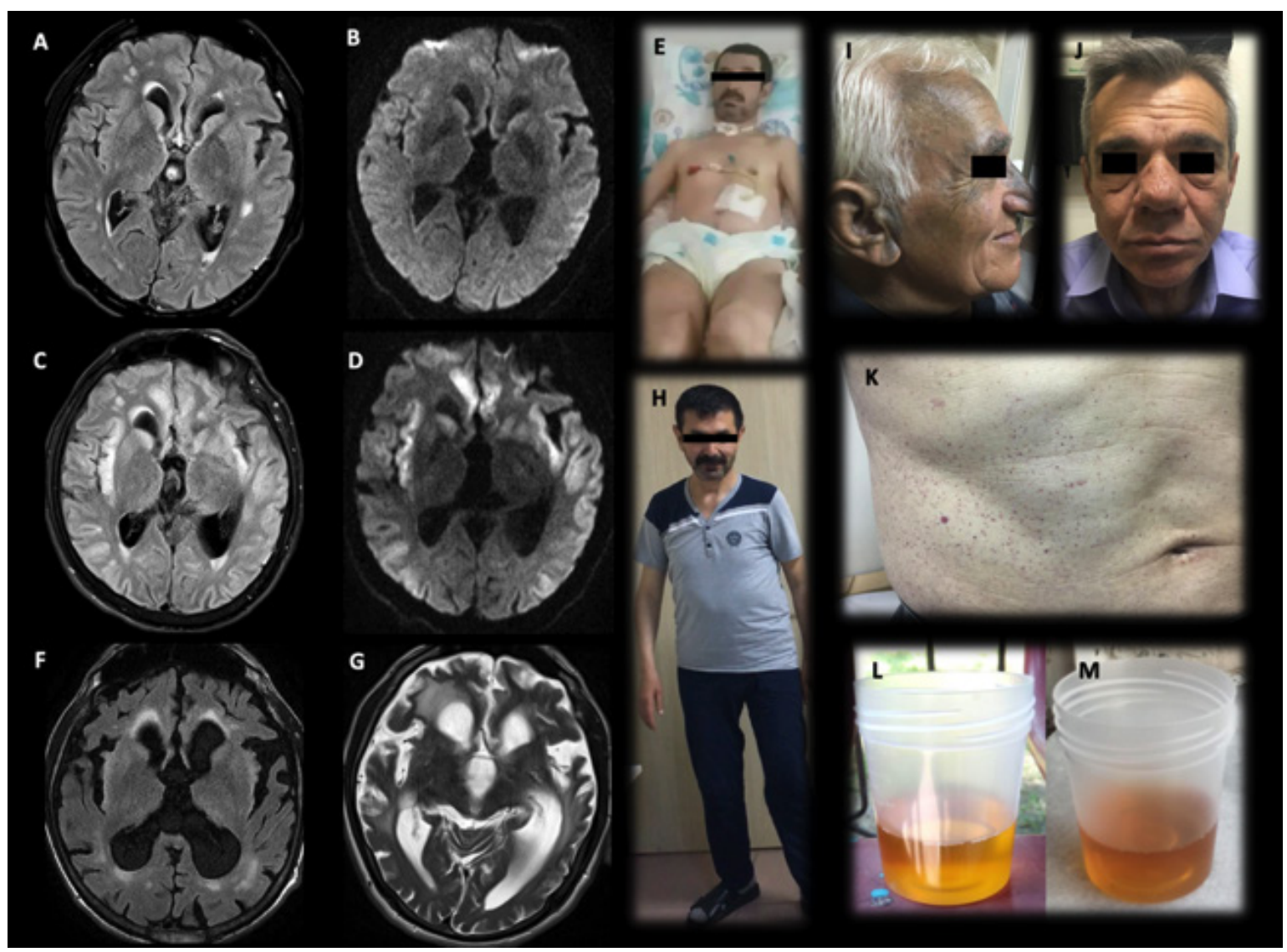

Resim 1. Kalıtsal metabolik hastalık tanısı alan erişkin olguların bazı fenotipik, radyolojik özellikleri

A-H: Sitrülinemi Tip 2 (Olgu I-1) A-B, Dezoryantasyon ve nöbet ile ilk başvurduğunda beyin MRG'de periventriküler derin yerleşimli özgül olmayan kortikal milimetrik plaklar (A-FLAIR, B-DWI) C-D, Yatışının 53. gününde bilinci kapalı iken, bilateral singulat girus, insüler ve temporal kortekste yüksek sinyalli lezyonlar ve diffüzyon kısıtlanması (C-FLAIR, D-DWI) E, Tanıdan 1 ay sonra bilinci açık taburcu edildiğinde klinik durumu F-G, Tedavinin 2. ayında görüntülemede sekel serebral atrofi (F-FLAIR, G-T2 TSE) H, Tanıdan 2 yıl sonra, son kontrolde klinik durum. I, Alkaptonüri (Olgu IV6), yüzde tipik okranozis; J-K, Fabry Hastalığı (Olgu IX-25), tipik yüz ve küme anjiyokeratomlar; L-M, Akut intermitan porfiri (Olgu VI-9'un oğlu), yeni geçirilmiş atak sonrasında taze idrar ve ışıkta bekletildikten sonra koyulaşan ve bulanıklaşan idrar.

diyet tedavisi başlanmıştır. Porfiri olgusunda atağı tetikleyebilecek ilaçlar kesilmiştir. Tüm olguların \%54'ü $(n=21)$, semptomatik olguların ise $\% 70$ 'i düzenli takibe gelmiş, 18 olgunun (9 semptomatik) ise uzun dönem izlemi yoktur. MNGIE olgusu, hastalığın kötü seyri nedeniyle hayatını kaybetmiştir. Çocuk olgular da eklendiğinde (indeks olgular ve tarama ile saptanan asemptomatik olgular), 14 aileden toplam 50 olgu $\mathrm{KMH}$ tanısı almıştır. Ülkemizde görece sık olduğu düşünülen 4 hastalığa dikkat çekmek için 4 olgu detaylı olarak sunulmuştur.

Enteral beslenme solüsyonu ile derinleşen koma: Ani bilinç kaybı nedeniyle acil servise getirilen 48 yaşındaki erkek olgunun
(Tablo 1, Olgu 1), 5 gündür bulantı, kusma, ishal ve dengesiz yürüme yakınmasının olduğu, başvurduğu hastanede gastroenterit ve vertigo için semptomatik tedavi verildiği öğrenildi. Bilincinin konfüze olması dışında nörolojik muayenesi, beyin tomografisi ve EEG'si normal saptanan olgu, bir kez jeneralize tonik klonik vasıfta nöbet geçirmesi üzerine valproik asit başlanarak taburcu edilmişti. Evde anlamsız davranışlarının (elbise dolabını tuvalet sanma) devam etmesi üzerine izlem amaçlı nöroloji servisine yatırımış, bilinç durumundaki dalgalanma nedeniyle tekrarlanan EEG'de nonkonvülzif status epileptikus saptanmıştı. Ilımlı amonyak (NH3: $120 \mu \mathrm{mol} / \mathrm{L}$; normal<50 $\mu \mathrm{mol} / \mathrm{L}$ ) ve transaminaz yüksekliği nedeniyle valproat 
kesilerek levetirasetam tedavisi başlanmıştı. Haftalar içinde bilinci gittikçe kapanan, beyin görüntülemesinde ventriküllerde genişleme, periventriküler derin yerleşimli kortikal milimetrik plaklar (Resim 1, A-B) saptanan, enfeksiyöz ve paraneoplastik etiyolojiler dişlanan olguya, otoimmün ensefalit ön tanısı ile pulse-steroid ve IVIG tedavileriverilmiş, ancakyanıtalınamamıştı. Nöbetleri üçlü antiepileptik tedavi ile kısmen kontrol altına alınabilen olgu, yatışının ikinci ayında trakeostomili olarak ve ağrılı uyaranları lokalize edemez durumda anestezi yoğun bakıma devredilmişti. Tekrarlanan beyin MRG'de bilateral singulat girus, insüler ve temporal kortekste yüksek sinyalli lezyonlar ve diffüzyon kısıtlanması (Resim 1, C-D) saptanması üzerine beyin biyopsisi ile Creutzfeldt-Jakob Hastalığı dışlanmıştı. Doktor yakını olması nedeni ile öyküsünden haberdar olunan olgu, yatışının 3 . ayında değerlendirildiğinde, kan biyokimyasında hipoalbuminemi, hipertrigliseridemi, ılımlı kolestaz dikkat çekti. Tekrarlanan plazma amonyak düzeyi normal saptandı, plazma amino asitlerinde sitrülin yüksekliği (522 $\mu \mathrm{mol} / \mathrm{L}$, normal: 17-43) ve eşlik eden arjinin yüksekliği (244 $\mu \mathrm{mol} / \mathrm{L}$, normal: 54-130) saptandı. Klinik, radyolojik ve biyokimyasal verilerle Sitrin eksikliği (Sitrülinemi tip-2; CTLN2) düşünülen olgunun eşinden beslenme öyküsü alındı, olgunun yağlı yemekleri çok sevdiği, meyve, tatlı, ekmek, pilav gibi yüksek karbonhidratlı gıdaları hiç tüketmediği öğrenildi. CTLN2 için çok tipik olan bu beslenme öyküsü nedeniyle, standart enteral beslenme solüsyonu ile düzenlenen beslenmesi hemen kesilerek yerine düşük glisemik indeksli, orta zincirli yağlardan (MCT) zengin enteral beslenme solüsyonu başlandı. Toksik metabolitlerin uzaklaştırılması amacıyla iki gün süreyle uygulanan plazmaferez sonrasında olgunun bilinci açıldı. İzlemde MCTyağı, L-Arjinin, sodyum piruvat takviyeleri de tedaviye eklendi, olgu sekel ile 3 hafta sonra taburcu edildi (Resim 1-E). SLC25A13 geninde homozigot patojenik varyant saptanarak CTLN2 tanısı kesinleştirildi. Tedavinin ikinci ayında görüntülemesinde sekel beyin atrofisi (Resim 1-F, G) olan olgu, ikinci yılda bağımsız yürüyebiliyor, hastalığını anlatabiliyor, günlük yaşam aktivitelerini yardımla yerine getirebiliyordu (Resim 1-H). Aile taramasında iki etkilenmiş birey (Olgu 2 ve 3 ) daha saptandı, her ikisi de tipik beslenme öyküsü tarif ediyordu. Bölgesel nöroloji toplantısında bu ailenin sunulmasını takiben bir olgu (Olgu 4) daha
CTLN2 tanısı aldı. Bildiğimiz kadarıyla bu olgular ülkemizde tanı alan ilk erişkin CTLN2 olgularıdır.

Bir vitaminle iyileşen kas hastalığı: 34 yaşında kadın olgu (Tablo 1, Olgu 36) oğlunun $\mathrm{KMH}$ tanısı alması ve kendisinin de benzer yakınmaları olması nedeniyle değerlendirilmek üzere çağrıldı. Altı aydır ilerleyen kas güçsüzlüğü ve çabuk yorulma yakınmaları olan 16 yaşındaki oğlu, şiddetli bacak ağrısı ve yürüyememe nedeniyle hastaneye getirildiğinde rabdomiyoliz (CK: 150.000 Ü/L) tablosunda olduğu görüldü. Destek tedavisi altında hızla solunum ve böbrek yetmezliği gelişen olgu yoğun bakıma alındı. Yağ asidi oksidasyon bozukluğu ön tanısı ile, plazma karnitin ve açilkarnitin düzeyleri çalışılmak üzere Guthrie kartına kan damlatılarak oda ısısında saklandı, organik asitler çalışılmak üzere 10 $\mathrm{ml}$ idrar donduruldu ve Riboflavin 3x100 mg, Koenzim Q10 2x100 mg, L-karnitin 2x1 gram takviyeleri nazogastrik aracılığı ile başlandı. Kırk sekiz saat içinde klinik bulgularında belirgin iyileşme olan olgunun açilkarnitin profilinde MADE ile uyumlu çoklu yükseklikleri saptandı, kas biyopsisi de lipit miyopati ile uyumlu olarak raporlandı. Anne değerlendirildiğinde, ilk kez gebeliğinin 1. trimesterinde baş düşmeleri şeklinde kas güçsüzlüğünün başladığı, düşükle sonuçlanan bir gebeliğin ardından yapılan kas biyopsisinde "inflamatuvar miyopati" saptanarak oral prednizolon tedavisi başlandığı, 10 yıldır steroid kullandığı, steroide bağlı gelişen bilateral katarakt nedeniyle opere olduğu, tip-2 diyabet ve osteoporoz için tedavi aldığı öğrenildi. Fizik bakıda Cushingoid görünümü, trunkal obezitesi, proksimal kas güçsüzlüğü (4/5), dört ekstremitede hipoaktif DTR'leri, eldiven çorap tarzı duyu kusuru saptanan olguya metabolik tetkik sonuçları beklenmeden MADE tedavisi başlandı. Birkaç hafta içinde efor kapasitesinde belirgin iyileşme gözlenen olgunun metabolik tetkikleri MADE ile uyumlu olarak sonuçlandı. Tedavinin birinci ayında steroid azaltılarak kesildi, insülin intiyacı kalmadı, tedavinin 6. ayında muayenesi tamamen normaldi. Tekerlekli sandalyede taburcu olan oğlu da, 1 ay sonra kontrole yürüyerek geldi (riboflavine yanıtlı-MADE). ETFDH geninde homozigot patojenik değişiklik saptanarak olguların tanıları kesinleştirildi. Aile ağacı çıkarıldığında, iki uzak kuzeninin ağır distal aksonal polinöropati nedeniyle yürüyemedikleri öğrenildi. Kontrole çağrılan iki kardeşinin (Olgu 37 ve 38) açilkarnitin 
profilleri normal, idrar organik asitleri MADE ile uyumlu saptandı ve genetik olarak tanıları kesinleştirildi. Ancak 6 ay süreyle uygulanan tedavi ile nöropatilerinde belirgin bir iyileşme olmadı (riboflavine yanıtsız-MADE).

Kronik yorgun ve hasta yakını bir anne: İki oğlu kliniğimizde takipli olan anne (Tablo 1, Olgu 33), kendisinin 1 yıldır olan kronik yorgunluk ve dengesizlik yakınmaları nedeniyle değerlendirildi. Acil servisimize yüksek ateş ve baş ağrısı yakınması ile getirilen 15 yaşında erkek olguda ense sertliği saptanmış, BOS direkt bakısı ve biyokimyası normal olan olgu, eşlik eden hiponatremi nedeniyle viral menenjit ön tanısı ile hastaneye yatırılmıştı. Hiponatremi etiyolojisinde adrenal yetmezlik, ve beyin MRG'de lökodistrofi saptanan olgu ALD düşünülerek bakılan plazma ÇUZYA profili ile ALD tanısı aldı. Aile taramasında 17 yaşındaki ağabeyi de aynı tanıyı aldı. Her iki olgunun 7 yaşlarından itibaren defalarca viral menenjit tanısı ile yatırılmış olmaları dikkat çekiciydi. Tanıları genetik olarak da kesinleştirilen olguların, üç ay sonra tekrarlanan görüntülemelerinde serebral lezyonların aktif olmadığı (kontrast tutmadığı) ve duraksadığı görüldü. Kök hücre nakli endikasyonu olmayan olgular Addison ve ılımlı miyelopati nedeniyle semptomatik tedavi ile izleme alındı. Her kontrolde, kendi konstitüsyonel yakınmalarından bahseden anneleri, heterozigot kadınların da semptomatik olabilmeleri nedeniyle ALD açısından değerlendirildi. Muayenede her iki alt ekstremitede derin duyu bozukluğu ve modifiye romberg pozitifliği mevcuttu, plazma ÇUZYA profili ALD uyumlu olarak anormal saptandı. Sinir iletileri EMG'de normal bulunurken, somatosensoryel uyarılmış potansiyel incelemesi miyelopati lehine bilateral alt ekstremitelerde anormal saptandı. Spinal MRG'de torakal spinal kordda en belirgin olmak üzere yaygın spinal atrofi yanı sıra T1-T2 düzeyinde sirinks varlığı görüldü. Her üç olguda, kısa süre uygulanan ÇUZYA-kısıtlı diyete hem uyum zorluğu hem de kanıtlanmış klinik etkinlik olmaması nedeniyle devam edilmedi. Miyelopatiye yönelik semptomatik antioksidan tedaviler ( $\mathrm{N}$-asetil sistein, $\mathrm{E}$ vitamini, Alfa lipoik asit) ve fizik tedavi desteği başlandı.

Babadan oğula miras şizofreni: 36 yaşındaki erkek olgu (Tablo 1, Olgu 9) şizofreni tanısı alan oğlu ile benzer yakınmalar olması nedeniyle değerlendirildi. On beş yaşındaki oğlu üç ay önce aniden başlayan işitsel halüsinasyonlar (penceren atlamasını söyleyen) ve sanrılar nedeni ile çocuk psikiyatri tarafından değerlendirimiş ve şizofreni tanısı ile risperidon başlanmıştı. Ailede yüklü psikiyatrik hastalık öyküsü nedeniyle araştırılmak üzere çocuk nöroloji tarafından değerlendirilen, nörolojik muayenesi, beyin görüntülemesi ve EEG'si normal saptanan olgu, olası $\mathrm{KMH}$ açısından değerlendirilmek üzere kliniğimize yönlendirilmişti. Öykü derinleştirildiğinde bir yıldır tekrarlayan karın ağrıları nedeniyle acil servis başvuruları olduğu, ailevi Akdeniz Ateşi hastalığının genetik test ile dışlandığı, bazı karın ağrısı ataklarında idrar renginin kırmızı olması nedeniyle taş düşürdüğü sanılarak ürolojiye yönlendirildiği ancak tetkiklerde taş saptanmadığı öğrenildi. Normalde sakin mizaçlı olan çocuğun, annesi tarafından yine bu ataklar sırasında aşırı sinirli davranışlar sergilediği belirtildi. Atakta olmamasına rağmen, spot idrar alınarak güneşte 3 saat bekletildiğinde, renginde koyulaşma ve bulanıklaşma olduğu dikkat çekti (Resim 1-L, M). İdrar porfobilinojen, total porfirin ve aminolevulinik asit (ALA) düzeyleri normal saptandı, atağın yakalanamadığı düşünüldü, hastalığı tetikleyebilecek ilaçlardan olan risperidon, çocuk psikiyatri gözetiminde kesildi ve yeni ilaç gereksinimi olmadı. Akut intermitan porfiri için yapılan HBMS gen sekansı normal saptandı. Babanın, lise yıllarında el ve ayaklarında yanma şeklinde ağrı ataklarının başladığı, bu dönemlerde duygularını ve davranışlarını kontrol etmekte zorlandığı, psikoz tanısı ile psikiyatrik ilaçlar kullandığı, çok sayıda iş değiştirmek zorunda kaldığı ve evliliğini yürütemediği, son yıllarda atakların azalarak yerini kronik yanma, karıncalanma gibi duyusal yakınmalara bıraktığı, EMG'lerde anlamlı bulgu saptanmadığı, nöropatik ağrı, hipertansiyon ve diyabete yönelik semptomatik tedaviler aldığı, el sırtlarında hiperkeratoz şeklinde başlayıp leke bırakarak iyileşen lezyonları olduğu, babasının ve üç kardeşinin de psikiyatrik tedaviler aldığı öğrenildi. Nörolojik muayenesi normal saptanan olgunun idrar porfobilinojen düzeyleri normal, ancak idrar üroporfirin ve ALA düzeyleri akut nöropatik porfiri lehine yüksek bulundu. İlaçları porfiriye göre revize edildi ve cilt tutumu olan akut porfiriler (Variagete porfiri, Herediter koproporfiri) için genetik test planlandı. 


\begin{tabular}{|c|c|c|c|c|}
\hline 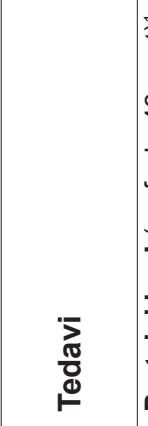 & 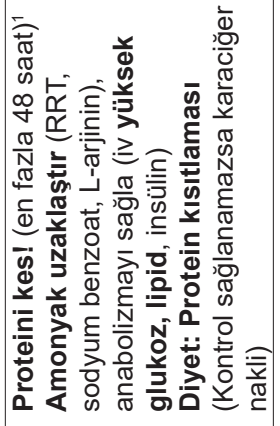 & 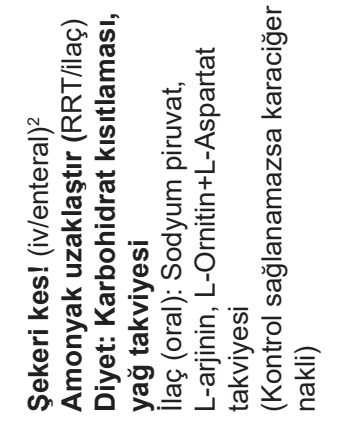 & 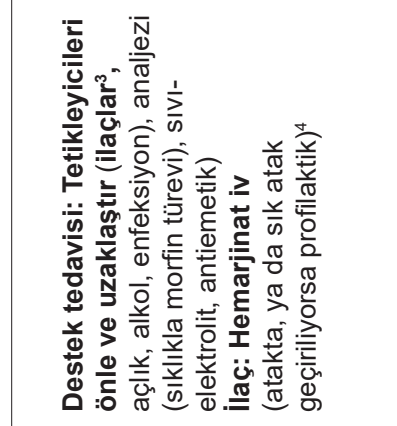 & 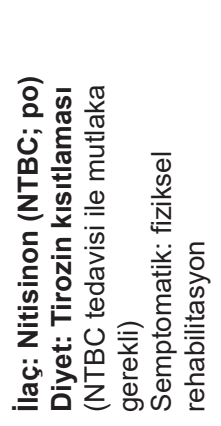 \\
\hline 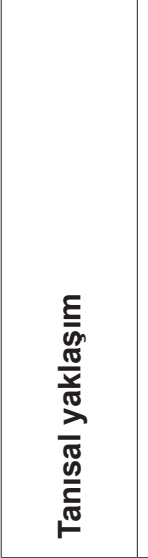 & 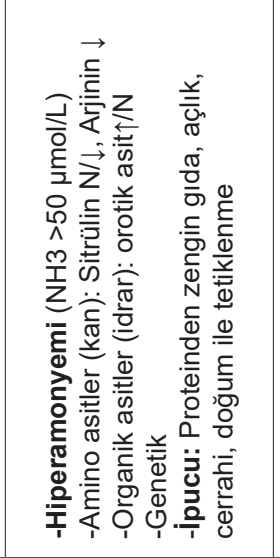 & 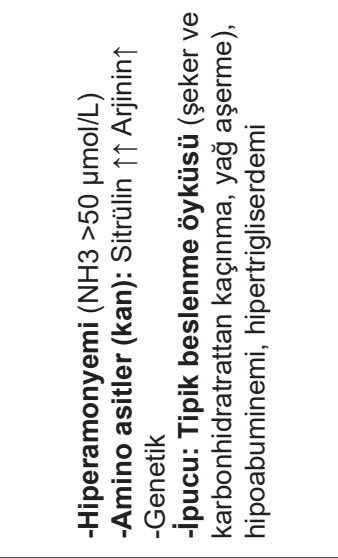 & 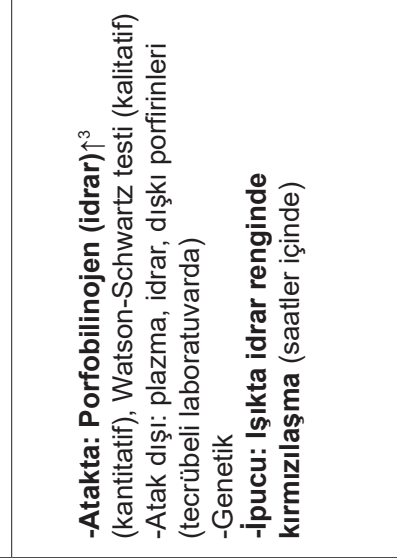 & 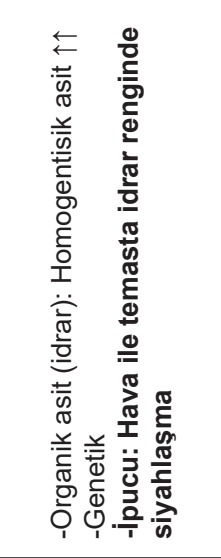 \\
\hline 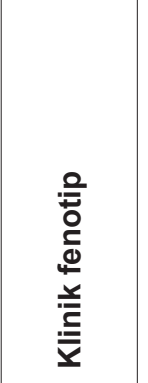 & 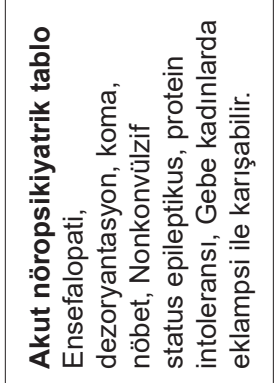 & 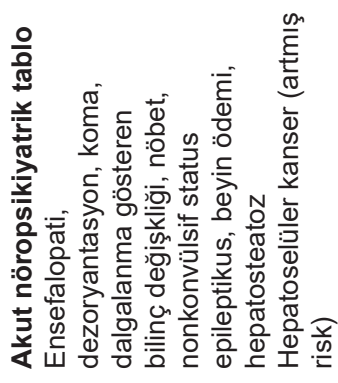 & 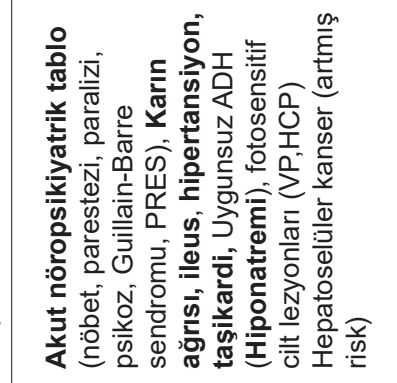 & 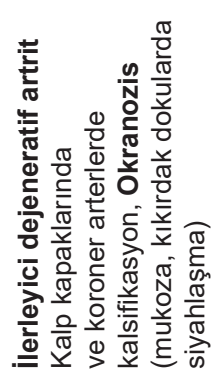 \\
\hline 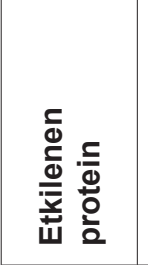 & 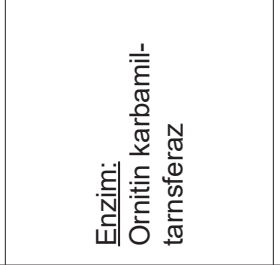 & 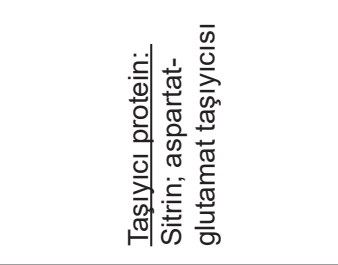 & 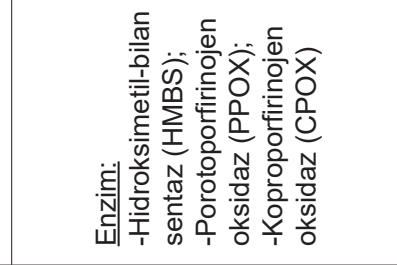 & 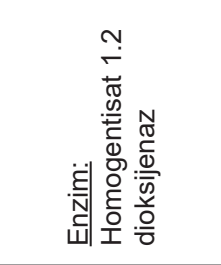 \\
\hline 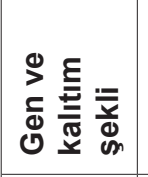 & $\begin{array}{l}\frac{\sqrt{\overline{7}}}{0} \\
0 \stackrel{0}{0} \\
\\
\end{array}$ & 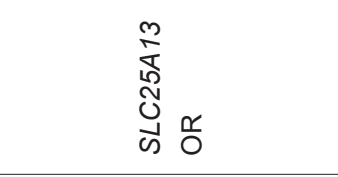 & 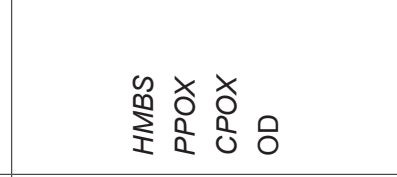 & 옹 뭉 \\
\hline 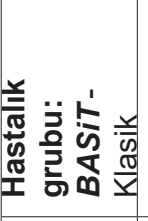 & 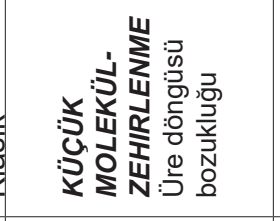 & 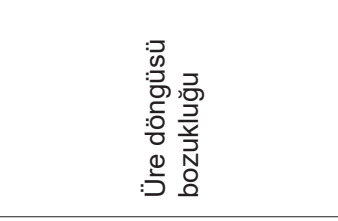 & 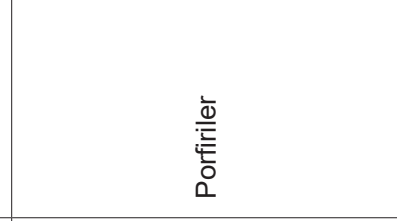 & 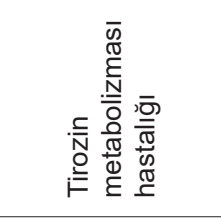 \\
\hline 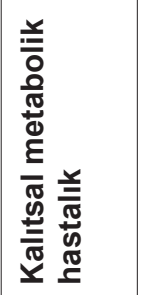 & 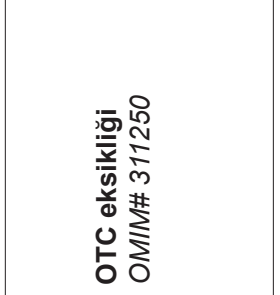 & 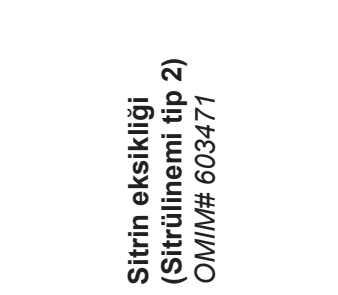 & 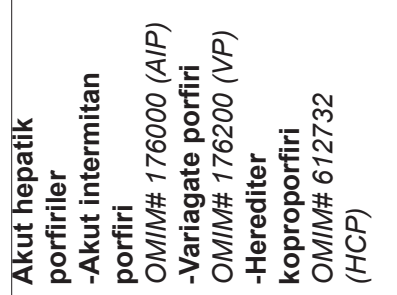 & 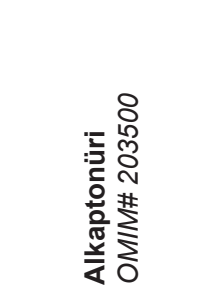 \\
\hline
\end{tabular}




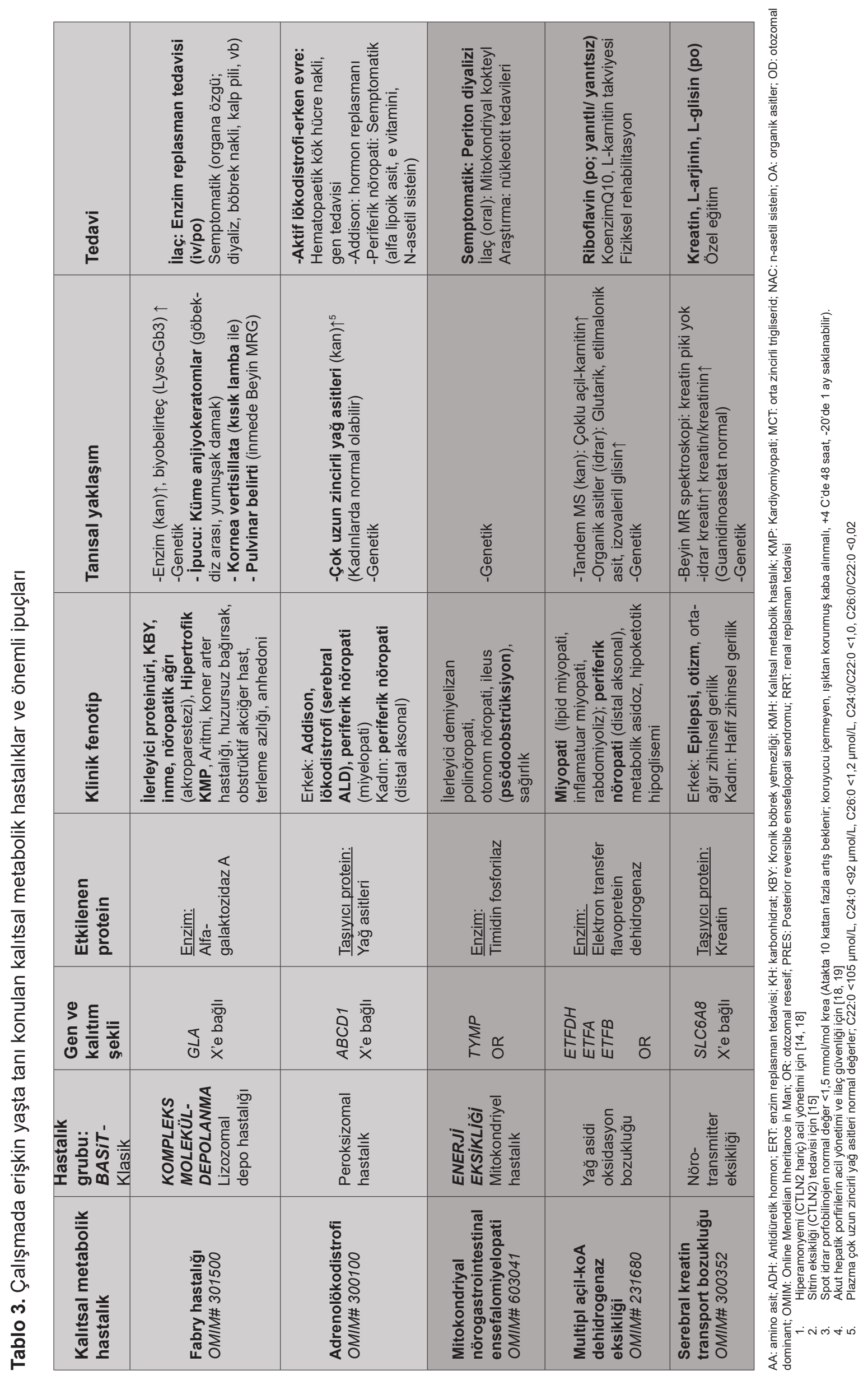




\section{Tartışma}

Erişkin başlangıçlı kalıtsal metabolik hastalıklar, tedavi edilme potansiyelleri ile öne çıkan genetik hastalıklardır [4]. Bu çalışma ile erişkin yaşta $\mathrm{KMH}$ tanısı almış 39 bireyin tanı, tedavi, izlem yolculuklarının olgu örnekleri ile sunulması ve KMH'ların klinik fenotipleri hakkında hekimlerin farkındalıklarının arttırııması amaçlanmıştır. Çalışmamızda tanı alan kalıtsal metabolik hastalıklar ve temel özellikleri Tablo 3'te özetlenmiştir.

Çalışma grubumuzda erişkin yaşta en sık tanı konulan hastalık Fabry olmuştur. Fabry hastalığı, mitokondriyal hastalıklarla birlikte dünya genelinde erişkin yaşta en sık tanı alan KMH'dır [8]. Ülkeler ve merkezler arasında farklııklar olmakla birlikte, Gaucher hastalığı, klasik homosistinüri, adrenolökodistrofi, Pompe hastalığı, glikojen depo hastalığı tip-V (McArdle), porfiriler, OTC eksikliği, sitrin eksikliği (CTLN2) erişkin yaşta sık tanı konulan diğer KMH'lardır $[8,9]$. İsviçre'de bulunan özelleşmiş bir erişkin $\mathrm{KMH}$ kliniğinin 4 yıllık tecrübesinin paylaşıldığı güncel bir çalışmada, merkezde izlenen 126 olgudan 19'unun (\%15) erişkin yaşta tanı aldıkları, diğerlerinin ise çocuk metabolizma kliniklerinden devir alındıkları, erişkinlerin sıklıkla mitokondriyal hastalık, homosistinüri ve Pompe hastalığı tanıları aldıkları dikkat çekmektedir [10]. Suudi Arabistan'dan bildirilen 485 olguluk benzer bir seride ise, 28 (\%6) olgunun erişkin yaşta tanı aldıkları ve başlıca tanıların tirozinemi tip 2 ve mitokondriyal hastalıklar olduğu görülmektedir [11].

Çalışmamızın en çarpıcı bulgusu, erişkin $\mathrm{KMH}$ olgularının klinik tanı alma oranlarındaki düşüklüktür. Semptomatik olguların yaklaşık dörtte üçü, vaskülit, inflamatuvar miyozit, periferik nöropati, astım, huzursuz barsak, osteoartrit, psikoz gibi özgül olmayan tanılarla izlemde iken, bir akrabalarının $\mathrm{KMH}$ tanısı alması nedeniyle yapılan aile taramasında gerçek tanılarına kavuşmuşlardır. Her bir $\mathrm{KMH}$ için erişkindeki özgül klinik fenotiplerin öğrenilmesi ile bu tanısal gecikmelerin önüne geçilebilecektir. Olgu serimizde öne çıkan klinik fenotipler; hiperamonyemi için dalgalı bilinç değişikliği, non-konvülzif status epileptikus; CTLN2 için hiperamonyemi ve şeker/karbonhidrat intoleransı; akut porfiriler için ataklar şeklinde karın ağrısına eşlik eden nöropsikiyatrik yakınmalar, hiponatremi ve idrar renginde kırmızılaşma; AKU için ilerleyici dejeneratif osteoartrit, okranozis, idrar renginde hava ile temasta siyahlaşma; Fabry hastalığı için böbrek yetmezliği, inme, akroparestezi, küme anjiyokeratomlar, kornea vertisillata; MADE için lipit/ inflamatuvar miyopati, tekrarlayan rabdomiyoliz ataklarıdır. Yakın zamanda ülkemizden bildirilen geniş bir MADE serisinde, özellikle riboflavine yanıtlı olguların halsizlik, kas güçsüzlüğü, kas ağrısı, yutma güçlüğü, solunum yetmezliği, bilinç bulanıklığı gibi yakınmalarla başvurdukları merkezlerde inflamatuvar miyopati, kas glikojen depo hastalığı, Romatolojik hastalık, Brusella, siklik kusma, Guillain-Barre sendromu gibi tanılar alarak yanlış tedavilere maruz kaldıkları ve asıl tanılarının ortalama 2 yıl geciktiği dikkat çekmektedir [12]. Her bir KMH için erişkindeki özgül klinik fenotiplerin öğrenilmesi ile bu tanısal gecikmelerin önüne geçilebilecektir.

Olgu serimizdeki en sık genetik kalıtım paterni, Fabry hastalarının sayıca çokluğu nedeniyle X'e bağlı kalıtım olmuştur. Fabry, ALD, OTC eksikliği, serebral kreatin transport bozukluğu gibi X'e bağı kalıtılan hastalıklar için heterozigot kadınların sadece taşıyıcı olmadıkları, rastlantısal $X$ inaktivasyonu (liyonizasyon)fenomeninedeniylehastalıklardan farklı derecelerde etkilenebildikleri bilinmektedir [13]. Çalışmamızda, X'e bağlı kalıtılan KMH'lar için heterozigot 21 kadın olgudan 12 'si semptomatik iken, 9'u asemptomatiktir. Genişletilmiş aile taramaları ile heterozigot kadınların saptanmaları, hem bu olguların doğru tanı, tedavi ve izlemleri için, hem de sonraki nesillerde ağır hasta erkek doğmasının önlenmesi için çok önemlidir.

Kalıtsal metabolik hastalık tanısı, olguların yarısında ileri biyokimyasal testler ile diğer yarısında ise genetik testler ile konulmuştur. Metabolik testler olarak da adlandırılan bu özelleşmiş biyokimyasal testlerin uygun endikasyonda ve doğru zamanda istenmeleri özgül KMH tanısına ulaşmada çok kıymetlidir. Örneğin Ramazan ayında iftar saatine yakın rabdomiyoliz tablosunda acil servise getirilen bir genç erişkin olguda uzamış açlığa rağmen idrar tetkikinde keton saptanmaması nedeniyle yağ asidi oksidasyon bozukluğu düşünen ve bu tanı için atak sırasında alınacak Tandem MS tetkikinin ne kadar kıymetli olduğunu bilen bir hekim, kuru kan kartlarını acil servis ve 
yoğun bakımda hazır bulundurmak isteyecektir. Mitokondriyal hastalıklar ya da X'e bağlı kalıtılan hastalıklardan etkilenmiş kadın olguların saptanmasında biyokimyasal testler yeterli olmamakta, özgül KMH tanısı genetik testler ile konulmaktadır. Bacaklarda his kaybı, spastik duruş, idrar ve dışkı inkontinansı yakınmaları ile başvuran 55 yaşındaki kadın olguda, yavaş ilerleyen miyelonöropati kliniği nedeniyle ALD düşünün bir nöroloji uzmanı, plazma ÇUZYA düzeyleri kadın olguların \%20'sinde normal olabileceği için, $A B C D 1$ gen analizi ile hastalığı ekarte etmek isteyecektir [4].

Çalışmamızda semptomatik olguların hemen tamamına yakınında (\%93), ilaç ve/veya özel diyet şeklinde, hastalığa özgü bir tedavinin mevcut olduğu görülmekte ve hastaların özgül tanılarına kavuşmalarının neden önemli olduğunu çarpıcı bir şekilde ortaya koymaktadır. Kesin tanı ve tedavi endikasyonuna rağmen, tedavi ve/veya izlemi reddeden olguların olduğu da görülmektedir. Tedavinin yarattığı psikososyal yük (ömür boyu, iki haftada bir, hastanede yatarak, damardan uygulanan enzim replasman tedavisi), etiketlenme korkusu, düşük eğitim seviyesi gibi birçok faktör tedavi reddine neden olabilmektedir. Bu durmlarda, hastanın kararları anlayışla karşılanmalı, güvendiği hekimler ya da yakınları sürece dahil edilerek, hastalık ve tedavinin önemi sabırla yeniden anlatılmalıdır [8]. Özgül tedaviler kadar, hiperamonyemi tedavisi gibi özgül olmayan ama hayati tedaviler de morbidite ve mortalitenin azaltılmasında çok önemlidir. Her türlü akut nöropsikiyatrik tabloda kan amonyak düzeyine bakılmalı ve yüksek düzeylere (NH3> $50 \mu \mathrm{mol} / \mathrm{L})$ hızlı müdahele edilmelidir [14]. Günümüzde halen kan amonyak düzeyi gibi temel bir tetkikin her hastanede yapılamıyor olması, hekimler için önemli bir engeldir [4]. Hiperamonyemi saptandığında, mümkünse aileden beslenme öyküsü alınarak sitrin eksikliği güvenle dışlandıktan sonra, yüksek glikozlu intravenöz SıVı ve protein kısıtlaması şeklindeki standart amonyak düşürücü tedaviye başlanmalıdır [14, 15]. Beslenmenin tıbbi bir müdahale olduğu ve klinik kötüleşmeden direkt sorumlu olabileceği her zaman akılda tutulmalıdır.

Sonuç olarak, ülkemizde ve dünyada erişkin kalıtsal metabolizma hastalıkları gittikçe büyüyen bir tıp alanı olarak dikkat çekmektedir ve bu alanda uzmanlaşmış hekimlerin yetişmesine intiyaç vardır [16]. Erişkinlerde özgül $\mathrm{KMH}$ tanısına ulaşmadaki en önemli ilk basamak, olguların klinik ve biyokimyasal fenotiplerinin (rabdomiyoliz, hiperamonyemi, miyelopati, vb.) saptanmasıdır. Olgudaki fenotipin özgül $\mathrm{KMH}$ ile ilişkilendirilebilmesi ise bundan sonraki önemli adımdır. Hekimlerin KMH'lar ile ilgili hissettikleri bilgi ve tecrübe eksiği, ayırıcı tanılar arasında sıklıkla karşılaştıkları bu hastalıkların tanı ve tedavi sorumluluğunu üstlenmekten çekinmelerine neden olabilmektedir. Hedeflenen her bir hastalığın klinik fenotipi, önemli ipucu, tanı yöntemi ve birinci basamak tedavisiyle birlikte tıp fakültesi ve uzmanlık eğitimlerinde öğretilmesi ile hekimler bu hastalıklara karşı kendilerini daha hazır hissedeceklerdir.

Çıkar ilişskisi: Yazarlar çıkar ilişkisi olmadığını beyan eder.

\section{Kaynaklar}

1. Jean Marie Saudubray, Angela Garcia Cazorla. Clinical Approach to Inborn Errors of Metabolism In: JeanMarie Saudubray, Matthias R. Baumgartner John Walter Eds. Ed. Inborn Metabolic Diseases 6th edition. Springer Berlin, Heidelberg, 2016;3-69.

2. Scriver CR. Garrod's Croonian Lectures (1908) and the charter 'Inborn Errors of Metabolism': albinism, alkaptonuria, cystinuria, and pentosuria at age 100 in 2008. J Inherit Metab Dis 2008;31:580-98. https://doi. org/10.1007/s10545-008-0984-9

3. Inborn Errors of Metabolism Knowledgebase. Available at: http://www.iembase.org/. Accessed February 01, 2021

4. Saudubray JM, Mochel F. The phenotype of adult versus pediatric patients with inborn errors of metabolism. J Inherit Metab Dis 2018;41:753-756. https://doi.org/10.1007/s10545-018-0209-9

5. Hannah Shmouni F, Stratakis CA, Sechi A, et al. Subspecialty training in adult inherited metabolic diseases: a call to action for unmet needs. Lancet Diabetes Endocrinol 2019;7:82-84. https://doi. org/10.1016/S2213-8587(18)30369-3

6. Stepien KM, Geberhiwot T, Hendriksz CJ, Treacy EP. Challenges in diagnosing and managing adult patients with urea cycle disorders. J Inherit Metab Dis 2019;42:1136-1146. https://doi.org/10.1002/ jimd.12096

7. Saudubray JM, Mochel F, Lamari F, Garcia Cazorla A. Proposal for a simplified classification of IMD based on a pathophysiological approach: a practical guide for clinicians. J Inherit Metab Dis 2019;42:706-727. https:// doi.org/10.1002/jimd.12086 
8. Sirrs S, Hollak C, Merkel M, et al. The frequencies of different inborn errors of metabolism in adult metabolic centres: report from the SSIEM adult metabolic physicians group. JIMD Rep 2016;27:85-91. https:// doi.org/10.1007/8904_2015_435

9. Pérez López J, Ceberio Hualde L, García Morillo JS, et al. Clinical characteristics of adult patients with inborn errors of metabolism in Spain: a review of 500 cases from university hospitals. Mol Genet Metab Rep 2017;10:92-95. https://doi.org/10.1016/j. ymgmr.2017.01.011

10. Gariani K, Nascimento M, Superti Furga A, Tran C. Clouds over IMD? Perspectives for inherited metabolic diseases in adults from a retrospective cohort study in two Swiss adult metabolic clinics. Orphanet J Rare Dis 2020;15:210. https://doi.org/10.1186/s13023-02001471-z

11. Sulaiman RA, Al Owain M. Inherited metabolic disorders in adults: a view from Saudi Arabia. Eur J Med Genet 2019;62:103562. https://doi.org/10.1016/j. ejmg.2018.10.014

12. Yıldız Y, Talim B, Haliloglu G, et al. Determinants of riboflavin responsiveness in multiple Acyl-CoA dehydrogenase deficiency. Pediatr Neurol 2019;99:6975. https://doi.org/10.1016/j.pediatrneurol.2019.06.015

13. Ortiz A, Germain DP, Desnick RJ, et al. Fabry disease revisited: management and treatment recommendations for adult patients. Mol Genet Metab 2018;123:416-427. https://doi.org/10.1016/j. ymgme.2018.02.014

14. Häberle J, Burlina A, Chakrapani A, et al. Suggested guidelines for the diagnosis and management of urea cycle disorders: first revision. J Inherit Metab Dis 2019;42:1192-1230. https://doi.org/10.1002/ jimd.12100

15. Saheki T, Song YZ. Citrin Deficiency. 2005 Sep 16 [updated 2017 Aug 10]. In: Adam MP, Ardinger HH, Pagon RA, Wallace SE, Bean LJH, Mirzaa G, Amemiya A, editors. GeneReviews ${ }^{\circledR}$ [Internet]. Seattle (WA): University of Washington, Seattle; 1993-2021.

16. Sechi A, Fabbro E, Langeveld M, Tullio A, Lachmann R, Mochel F. SSIEM Adult Physicians Metabolic Group. Education and training in adult metabolic medicine: results of an international survey. JIMD Rep 2019;49:63-69. https://doi.org/10.1002/jmd2.12044

17. Taskıran E, Tas MY, Hismi B, et al. A late diagnosis of alkaptonuria in an elderly patient. Eur Ger Med 2017;8:178-180. https://doi.org/10.1016/j. eurger.2016.12.007

18. British Inherited Metabolic Disease Group Emergeny Guidelines. Available at: https://www.bimdg.org.uk. Accessed February 01, 2021

19. American Porphyria Foundation Safe/Unsafe Drug Database. Available at: https://porphyriafoundation. org. Accessed February 01, 2021
Teşekkür: Dr. Feray Güleç Uyaroğlu, Dr. Harun Akar, Dr. Selim Ekinci, Dr. Figen Baydan başta olmak üzere hastalarını bölümümüze konsülte eden ve olguları birlikte izlediğimiz Tepecik Eğitim Araştırma Hastanesi'ndeki tüm hekim arkadaşlarıma, hastalarımıza verdikleri tanısal destek için Dr. Aybüke Günaslan Hastürk, Dr. Demet Arslan, Dr. Özgür Kırbıyık başta olmak üzere tüm tıbbi genetik ve biyokimya uzmanlarımıza, biyokimya metabolizma laboratuvarında ve genetik tanı merkezinde çalışan teknisyenlerimize ve son olarak, hayat hikayelerine misafir olmaktan onur duyduğum ve bu tecrübenin paylaşılmasını koşulsuz destekleyen tüm hastalarıma ve ailelerine sonsuz teşekkürlerimi sunarım.

Etik kurul onayı: Sağlık Bilimleri Üniversitesi İzmir Tepecik Eğitim ve Araştırma Hastanesi Girişimsel Olmayan Araştırmalar Etik Kurulu'nun 24/10/2019 tarih ve 2019/15-02 karar nosu ile onaylanmıştır. 